DOI: 10.34015/2523-4552.2021.1.04

УДК 343.8

Денисов С. Ф., доктор юридичних наук, професор, професор кафедри кримінального права та кримінології факультету № 6 Харківського національного університету внутрішніх справ ORCID 0000-0002-1218-0016

Заїка Д. $\epsilon$. аспірант кафедри кримінального права та кримінології факультету № 6 Харківського національного університету внутрішніх справ

\title{
МІЖНАРОДНО-ПРАВОВІ СТАНДАРТИ ЩОДО ВИПРАВЛЕННЯ ТА РЕСОЦІАЛІЗАЦІЇ ЗАСУДЖЕНИХ
}

Стаття присвячена аналізу міжнародних стандартів поводження із засудженими. Автори поставили за мету проаналізувати загальний масив нормативно-правових актів щодо наявності положень, які регулюють питання виправлення і ресоціалізації, та згрупувати їх за спільними ознаками.

Ключові слова: виправлення та ресоціалізація; міжнародний аспект; правила; декларація; Генеральна Асамблея ООН; конвенції ООН; резолюції; міжнародні стандарти поводження із засудженими.

Статья посвящена анализу международных стандартов обращения с осужденными. Авторы поставили цель проанализировать общий массив нормативно-правовых актов на наличие положений, регулирующих вопросы исправления и ресоциализации и сгруппировать их по общим признакам.

Ключевые слова: исправление и ресоциализация; международный аспект; правила; декларация; Генеральная Ассамблея ООН; конвенции ООН; резолюции; международные стандарты обращения с осужденными.

Постановка проблеми. Виправлення та ресоціалізація засуджених $€$ провідним завданням пенітенціарних систем більшості країн світу. Однією зі складових його ефективної реалізації є дотримання міжнародних стандартів. Проте, на сьогодні не існує єдиного нормативно-правового акту, направленого на врегулювання проблемних питань виправлення та ресоціалізації засуджених, отже виникає необхідність їх виокремлення та подальшої деталізації.

Постановка завдання. Метою цієї публікації $\epsilon$ виокремлення положень, що регулюють виправлення і ресоціалізацію серед загального масиву міжнародних стандартів поводження із засудженими. Для реалізації вказаної мети спробуємо вирішити такі завдання: проаналізувати чинні міжнародні нормативно-правові акти та матеріали вже існуючих науко- 
вих досліджень; виявити та дослідити серед них положення, що стосуються виправлення та ресоціалізації засуджених; об'єднати їх за спільними ознаками та сформулювати власні висновки.

Аналіз останніх досліджень і публікацій. За останні 10 років питання реалізації в Україні міжнародних стандартів поводження із засудженими досліджували: колектив авторів за заг. ред. А. Х. Степанюка щодо засобів виправлення засуджених до позбавлення волі (2011 р.); О. В. Таволжанський щодо соціально-виховної роботи (2014р.); О. М. Овчаренко щодо реформування органів кримінальної юстиції (2015р.); І. С. Яковець, К. А. Автухов, М. Ю. Кутєпов щодо кримінально-виконавчої політики України (2016 р.); О. І. Іваньков щодо захисту прав засуджених до позбавлення волі (2016 р.); О.В.Краснокутський щодо механізмів забезпечення прав засуджених (2019р.); I. О.Колб щодо заходів фізичного впливу (2019р.); О.М. Гальцова та А. Х. Степанюк щодо принципів поваги до прав і свобод людини (2020р.); Чалий I. C. щодо соціальної реабілітації засуджених (2021 р.) та ін. Проте міжнародно-правові стандарти, що регулюють питання виправлення та ресоціалізації засуджених у сукупності раніше досліджені не були, що і зумовлює актуальність вибору теми.

Виклад основного матеріалу. Виправлення та ресоціалізація засуджених $€$ складними багатофакторними процесами, окремі аспекти яких регламентуються на міжнародному рівні. У загальному - це правила, вимоги та положення, що спрямовані на вдосконалення внутрішнього законодавства шляхом встановлення мінімуму, дотримання яко- го $\epsilon$ обов'язковим для державучасниць, що підписали угоду, ратифікували декларацію чи інший документ та імплементували його у національне законодавство. Завдяки підвищеній стурбованості й увазі міжнародної спільноти до цих питань у різний час авторитетними міжнародними організаціями прийнято близько 300 декларацій, конвенцій та хартій $[1$, с. $125 ; 2$, с. $161 ; 3$, c. $133 ; 4$, с. 31 ].

У теорії вітчизняного кримінально-виконавчого права існує поняття «міжнародні стандарти поводження із засудженими», що означає прийняті на міжнародному рівні норми, принципи і рекомендації у галузі. На думку П. М. Рабіновича, термін «стандарти» найбільш точно відображає роль вказаних документів, адже їх пов'язують саме із міжнародно-правовими актами, які найповніше відображають надбання людства у цій сфері. Деякі принципи, що містяться у міжнародних актах, можуть виступати як загальні засади діяльності органів і установ виконання покарань. Інші ж, незважаючи на те, що вони спочатку були закріплені у міжнародних актах, можуть служити вихідними засадами лише для окремих інститутів кримінально-виконавчого законодавства. Міжнародні стандарти поводження із засудженими класифікують за низкою критеріїв. За масштабом дії виділяють універсальні та регіональні стандарти. За джерелами походження розрізняють норми, ухвалені міжнародними міжурядовими організаціями та норми, ухвалені неурядовими організаціями. За ступенем обов'язковості для державучасниць розрізняють обов'язкові та ті, що мають рекомендаційний ха- 
рактер. За спеціалізацією міжнародні стандарти поділяються на стандарти загального та спеціального характеру. Згодом було запропоновано оновлену сучасну модель класифікації міжнародно-правових стандартів Організації Об'єднаних Націй та Ради Європи у сфері забезпечення захисту прав засуджених до позбавлення волі за двома основними критеріями: загальні, які включають в себе загальні норми й правила, що стосуються прав людини, боротьби зі злочинністю та проблем удосконалення правосуддя; загальні стандарти у сфері забезпечення захисту прав всіх категорій засуджених і поводження із ними; і спеціальні, які визначають норми й правила, що стосуються визначених категорій засуджених до позбавлення волі, зокрема: жінок; неповнолітніх; осіб, взятих під варту; жертв злочину; засуджених до альтернативних видів покарань; засуджених до смертної кари; засуджених до довічного ув'язнення та інших тривалих строків покарання; уразливих категорій засуджених; персоналу установ виконання покарань. Наведений перелік класифікацій не $\epsilon$ вичерпним $[1$, c. $126-128 ; 5$, c. $23 ; 6$, c. $21,24-25$; 7, c. 6].

Стандарти загального характеру не покликані врегулювати безпосередньо роботу із засудженими, проте містять важливі положення, дотримання яких $€$ щоденним завданням української пенітенціарної системи та прямо впливають на якість виправлення та ресоціалізації засуджених. Так, відповідно до ст. 5 Загальної Декларації прав людини та ст. 7 Міжнародного пакту про громадянські й політичні права ніхто не повинен піддаватися катуванням або жорстокому, нелюдському чи такому, що принижує його гідність, поводженню й покаранню. Відповідно до ст. 8 останнього робота, яку повинна виконувати ув'язнена особа на підставі законного розпорядження суду не належить до "примусової чи обов'язкової праці” та не порушує права людини. Стаття 10 пакту закріпила, що всі особи, позбавлені волі, мають право на гуманне поводження і повагу до гідності, а частина 3 статті вказує, що пенітенціарною системою має бути передбачений такий режим для ув'язнених, істотною метою якого $\epsilon$ їх виправлення і соціальне перевиховання (reformation and social rehabilitation) $[1$, c. $129 ; 8 ; 9 ; 10$, c. 176 ; 11 , c. $639 ; 12$, c. 101$]$.

Акти спеціального характеру більш широко розкривають проблематику роботи із засудженими у загальному та їх виправлення i peсоціалізації окремо. Серед іншого, до них належать Мінімальні стандартні правила поводження 3 в'язнями (Правила Мандели) (1955, 2015 рр.), Декларація про захист усіх осіб від тортур та інших жорстоких, нелюдських, або таких, що принижують гідність, видів поводження і покарання (1975 р.), Конвенція проти катувань та інших жорстоких, нелюдських, або таких, що принижують гідність, видів поводження і покарання (1984 р.), Кодекс поведінки посадових осіб під час підтримання правопорядку (1979р.), Мінімальні стандартні правила ООН, що стосуються здійснення правосуддя щодо неповнолітніх (Пекінські правила) (1985р.), Звід принципів захисту всіх осіб, які піддаються затриманню чи ув'язненню будь-яким чином (1988р.), Правила ООН щодо захисту неповнолітніх, позбавлених 
волі (1990р.), Керівні принципи ООН запобігання злочинності серед неповнолітніх (Ер-Ріядські керівні принципи 1990 р.) [13; 14; 15; 16; 17; 18; $19 ; 20]$.

Мінімальні стандартні правила поводження 3 в'язнями (Правила Мандели) покликані забезпечувати захист засуджених осіб від зловживання повноваженнями посадовими особами, особливо в тому, що стосується підтримання дисципліни i застосування заходів наведення порядку в пенітенціарних установах. Правила були прийняті у 1955 році та адаптовані до вимог сьогодення у 2015 р. Відповідно до положень Мінімальних стандартних правил поводження 3 в'язнями фахівцями виправної установи повинні бути розроблені індивідуальні програми (правила 4, 88, 89, 91-94, 96-105), що передбачають освітню, професійну підготовку, роботу або будь-яку іншу допомогу, необхідну для реінтеграції (правило 4) та ресоціалізації засуджених, окрема увага (правила 106108) приділяється збереженню соціальних зв'язків ув'язнених. Серед іншого, у положеннях правила 122 (правило 95 за старою редакцією) згадуються виправлення та перевиховання (re-education or rehabilitation), які у контексті статті виступають ознакою засудження особи за вчинений злочин та не можуть бути застосованими до осіб, щодо яких немає вироку суду [13; 21 ; 22 , с. $35 ; 23$, с. $63-64 ; 24$, с. 54 ].

Щодо Резолюції Генеральної Асамблеї ООН “Декларація про захист усіх осіб від тортур та інших жорстоких, нелюдських, або таких, що принижують гідність, видів поводження і покарання" № 3452 від 09.12.1975, ст. 1 забороняє навмисно заподіюва- ти сильний біль або страждання, фізичні чи розумові, з боку офіційної особи або з метою отримання від утримуваного або від третьої особи інформації або зізнань, покарання його за дії, які він скоїв або в скоєнні яких підозрюється, або залякування його або інших осіб. А держава, відповідно до ст. 6 повинна систематично переглядати методи і практику ведення допиту і умови утримання під вартою і поводження з особами, позбавленими волі. Мигаль Р. В. зазначає, що особливе занепокоєння було проявлено світовим співтовариством, коли Декларація не виконала свого завдання та не була ефективною. Через дев'ять років ООН прийняла більш дієвий документ, присвячений цій проблемі - Конвенцію проти катувань та інших жорстоких, нелюдських або таких, що принижують гідність, видів поводження і покарання. Від Декларації вона відрізнялася не тільки обсягом, але головним чином, тим, що всі її положення мали обов'язковий характер для країн, які їі підписали. Серед іншого, відповідно до ст. 10 Конвенції кожна держава-сторона повною мірою забезпечує включення навчальних матеріалів та інформації про заборону катувань до програм підготовки персоналу органів чи посадових осіб, які можуть мати відношення до утримання під вартою й допитів осіб, які зазнали будьякої форми арешту, затримання чи ув'язнення. На жаль, у звітах Amnesty International зазначається, що тортури (катування) та інші види жорстокого поводження із засудженими $\epsilon$ негативним поширеним явищем у багатьох країнах світу. Не $\epsilon$ винятком і Україна. [14; 15; 25, с. 41; 26, c. 97]. 
Резолюція Генеральної Асамблеї ООН “Кодекс поведінки посадових осіб під час підтримання правопорядку" № 34/169 від 17.12.1979 у ст. 5 частково повторює положення Конвенції проти катувань та інших жорстоких, нелюдських або таких, що принижують гідність, видів поводження і покарання. Положення ст. 6 закріпили, що посадові особи 3 підтримання правопорядку забезпечують повну охорону здоров'я затриманих ними осіб i, зокрема, приймають негайні заходи щодо забезпечення надання медичної допомоги в разі потреби. У зв'язку з цим Кодекс має пряме відношення до діяльності персоналу установ і органів, які виконують покарання. Кодекс містить вісім статей і в цілому носить рекомендаційний характер $[11$, c. $644 ; 16]$.

Мінімальні стандартні правила $\mathrm{OOH}$, що стосуються здійснення правосуддя щодо неповнолітніх, (Пекінські правила) ставлять собі за мету створення умов, що дозволяють забезпечити належний рівень життя підлітка в суспільстві, у той період, коли він найбільш схильний до неправильної поведінки. Так, положення $\quad$ п. 19 та 19.1 передбачають мінімізацію використання заходів ув'язнення. Також п. 28 рекомендує регулярно якнайширше застосовувати раннє умовне звільнення 3 виправної установи. Відповідно до п. 26.1 метою виховної роботи (training and treatment) з неповнолітніми, що перебувають у виправних установах, $\epsilon$ забезпечення опіки, захисту, освіти та професійної підготовки, надання їм допомоги для виконання соціально-корисної ролі в суспільстві. Зазначається, що надання медичної та психологічної допомоги має виключно важливе значення для поміщених у виправні установи наркоманів, агресивних і психічно хворих молодих людей. 3 точки зору ресоціалізації п. 29.1 пропонує докладати зусиль для використання проміжних форм роботи, таких як виправні установи 3 ослабленим режимом, виховні будинки, центри денної підготовки та інші аналогічні їм установи, які можуть сприяти належній реінтеграції (reintegration) неповнолітніх до життя у суспільстві. Також необхідно передбачити допомогу і нагляд з боку посадової особи системи пробації або іншої уповноваженої посадової особи [17; 27, с. 72, 75; 28, с. 125].

Резолюцію Генеральної Асамблеї ООН “Звід принципів захисту всіх осіб, які піддаються затриманню чи ув'язненню будь-яким чином" № 43/173 було прийнято у 1988 p. Принцип 1 передбачає, що всі особи, піддані затриманню або ув'язненню, мають право на гуманне поводження і повагу до гідності. Принцип 5 вказує на необхідність застосування заходів захисту прав і особливого статусу жінок, особливо вагітних жінок, матерів-годувальниць, а також дітей, підлітків, престарілих, хворих або інвалідів, що не вважається дискримінацією. Принципом 6 було заборонено застосування катування. Відповідно до принципу 24 ув'язненим надається можливість пройти належне медичне обстеження, право на постійне медичне обслуговування та лікування за необхідності. Обслуговування та лікування надаються безкоштовно [18].

Резолюція Генеральної Асамблеї ООН “Правила ООН щодо захисту неповнолітніх, позбавлених волі" № 45/113 була прийнята 14 грудня 1990 року. Мета правил полягає у 
тому, щоб встановити мінімальні стандарти, відповідно до прав людини і основних свобод, протидіяти несприятливим наслідкам усіх видів ув'язнення та сприяти залученню неповнолітніх у життя суспільства. За п. 8 Правил компетентні органи повинні постійно прагнути забезпечити розуміння громадськістю того, що турбота про неповнолітніх, ув'язнених у виправних установах, і підготовка до повернення у суспільство $€$ важливим елементом їх діяльності, і 3 цією метою слід заохочувати встановлення вільних контактів між неповнолітніми і жителями місцевої громади. Пункт 27 передбачає, що у найкоротший термін з моменту надходження до місць позбавлення волі 3 кожним неповнолітнім повинна проводитися співбесіда і має бути підготовлений психологічний і соціальний звіт, у якому визначаються будь-які фактори, що мають відношення до конкретного виду і рівню догляду та конкретну програму, яка потрібна для даного неповнолітнього. Цей звіт поряд із доповіддю, підготовленою медичним працівником, який провів обстеження неповнолітнього після його прибуття, направляється директору для визначення місця для ув'язненого в рамках установи, а також конкретного виду і рівня догляду. Коли потрібні спеціальні заходи реабілітаційного (rehabilitative treatment) характеру і коли це дозволяють терміни перебування $\mathrm{y}$ виправному установі, кваліфікований персонал установи повинен підготувати у письмовому вигляді індивідуальний план заходів, конкретно вказавши їхні цілі, терміни і засоби, етапи і затримки, які повинні бути враховані в ході заходів, спрямованих на досягнення цих цілей. За п. 59 необ- хідно використовувати всі засоби для забезпечення належного зв'язку неповнолітніх із зовнішнім світом. Також заходи з ресоціалізації передбачені п. 71, за яким на всіх неповнолітніх повинні поширюватися заходи 3 надання їм допомоги при поверненні у суспільство та сімейне життя, їх навчання або працевлаштування після звільнення. 3 цією метою повинні розроблятися процедури, включаючи дострокове звільнення, i організовуватися спеціальні курси, а п. 80 зобов'язує державу надати належне житло, роботу, одяг і достатньо коштів для проживання після звільнення, $з$ тим щоб сприяти успішній реінтеграції (reintegration) неповнолітнього $[19 ; 20$, с. 4,$9 ; 30$, с. $125-$ 126].

Керівні принципи ООН запобігання злочинності серед неповнолітніх (Ер-Ріядські керівні принципи) було прийнято і проголошено резолюцією 45/112 Генеральної Асамблеї від 14 грудня 1990 року. Відповідно до п. 49 відправлення молодих осіб у виховно-виправні установи слід здійснювати як крайній захід і на мінімально необхідний термін, з урахуванням інтересів підлітка [20].

Резолюція Генеральної Асамблеї ООН “Мінімальні стандартні правила Організації Об'єднаних Націй у відношенні заходів, не пов'язаних 3 тюремним ув'язненням" (Токійські правила) № 45/110 була прийнята 14 грудня 1990 року. Відповідно до п. 2.4 слід заохочувати розробку нових заходів, не пов'язаних з тюремним ув'язненням, і уважно стежити за цим процесом, що має йти шляхом депеналізації та декриміналізації (п. 2.7.). Відповідно до п. 10.1. держава має встановити 
нагляд, мета якого полягає у тому, щоб скоротити рецидивну злочинність і сприяти такому включенню правопорушника у життя суспільства (integration into society) який звів би до мінімуму ймовірність повторного вчинення злочинів. За п. 13.1 з метою проведення більш ефективної роботи необхідно розробити такі методи, як індивідуальна робота, групова терапія, програми за місцем проживання і особливе поводження 3 різними категоріями правопорушників [31; 32, с. 122].

Ще один міжнародний документ, прийнятий 3 орієнтиром на виправлення та ресоціалізацію, - Правила ООН стосовно поводження 3 ув'язненими жінками і засобів покарання для жінок-правопорушниць без позбавлення їх свободи (Бангкокські правила). Відповідно до Національної стратегії у сфері прав людини на 2021-2023 рр., затвердженої указом Президента України від 24 березня 2021 року № 119/2021 вказаний акт має бути імплементованим в українське законодавство. Правила закріплюють положення про необхідність приділяти підвищену увагу здоров'ю засуджених жінок, націлюють роботу персоналу виправних установ на сприяння виправленню i подальшої реінтеграції засуджених, реалізуючи їх право на охорону здоров'я та медичну допомогу. Як закріплено в п. 40 Правил, тюремна адміністрація розробляє та впроваджує методи класифікації з урахуванням особливих потреб i обставин жінок-ув'язнених, обумовлених гендерними факторами, з тим, щоб забезпечити відповідне індивідуальне планування і здійснення роботи 3 якнайшвидшої реабілітації, виправлення i реінтеграції (rehabilitation, treatment and reintegration) цих ув'язнених у життя суспільства [24, с. 56; 33 , с. $81 ; 34$, с. $15 ; 35]$.

Окремої уваги заслуговують восьмий (1990, Гавана), дев'ятий (1995, Каїр), дванадцятий (2010, Сальвадор), тринадцятий (2015, Доха) та чотирнадцятий (2021, Кіото) конгреси ООН щодо запобігання злочинності та поводження 3 правопорушниками. На 8-ому Конгресі 1990 р. було прийнято понад 50 документів, більшість 3 яких направлено на вдосконалення міжнародного та національного кримінального права і кримінального процесу: Типові договори про видачу злочинців і про взаємну допомогу у кримінальних справах; Заходи по боротьбі 3 міжнародним тероризмом; Типовий договір про передачу кримінального нагляду за правопорушниками, які були умовно засуджені або умовно звільнені. На 9-ому Конгресі у 1995 р. були змінені пріоритети на користь захисту потерпілих і громадських інтересів, на відміну від традиційного захисту прав осіб, винних у скоєнні злочинів. На 12-ому Конгресі у 2010 р. розглянута Декларація про комплексних стратегій для відповіді на глобальні виклики: системи попередження злочинності та кримінального правосуддя. На 13-ому Конгресі у 2015 р. була підкреслена роль стандартів і норм ОOH у попередженні злочинності, а також необхідність використання у цих цілях соціальних мереж і комунікаційних технологій для залучення громадськості. У кримінальному судочинстві держав були відзначені тенденції до переходу від карального до реституційного правосуддя. На 14-ому Конгресі у березні 2021 р. було затверджено Проект Кіотської декларації 
про сприяння запобіганню злочинності, кримінальному правосуддю та верховенству права: до досягнення Порядку денного для сталого розвитку на 2030 рік [36, с. 23; 37, с. 16$18 ; 38$, с. $10-11,14-16 ; 39$, с. $6-9 ; 40$, c. $1 ; 41$, с. $1-3 ; 42$, с. $267-271]$.

Відповідно до п. 37 проекту держава повинна сприяти реабілітаційному (rehabilitative) середовищу у виправних закладах, у тому числі шляхом розробки та впровадження ефективних програм виправлення (treatment programmes) на основі індивідуальної оцінки потреб та ризиків правопорушників, а також забезпечити правопорушникам доступ до професійно-технічного навчання та освітніх програм 3 метою підтримки розвитку необхідних навичок для реінтеграції (reintegration). За п. 39 також рекомендується сприяти розвитку багатосторонніх партнерських відносин для зменшення кількості повторних правопорушень шляхом міжвідомчої координації державних органів, таких як агентства з питань зайнятості та соціального забезпечення та органів місцевого самоврядування, а також державно-приватне партнерство між цими органами влади та громадою, у тому числі співпрацюючих роботодавців та громадських волонтерів, які готові сприяти довгостроковій соціальній реінтеграції правопорушників. 3 цього приводу ще у 2013 році Т. А. Денисова вказувала на необхідність розробки кримінологічних відновлювальних програм, які давно використовуються у країнах Західної Європи, але досі залишаються недооціненими в Україні [43, с. $5-6 ; 44$, с. 422$]$.

У своїй резолюції 56/119 про роль, функції, періодичність і три- валість конгресів ООН щодо запобігання злочинності та поводження $з$ правопорушниками Генеральна Асамблея постановила, що кожному Конгресу передують, коли це необхідно, регіональні підготовчі наради як один із ключових механізмів підготовки зазначених форумів. Їх метою $є$ обговорення питань щодо забезпечення врахування актуальних для окремих регіонів проблем у роботі відповідних Конгресів ООН та, власне, визначення таких проблем. Загалом конгреси ООН, та прийняті на них документи суттєво вплинули на розвиток національного кримінального та кримінальновиконавчого права. Чимало з проголошених прав ще п'ятдесят років тому визнані такими, що заслуговують подальшого вивчення i дослідження (наприклад, згода осіб, які тримаються під вартою, на здійснення щодо них програм виправних заходів; практика залучення до праці таких осіб на добровільних засадах, тримання осіб, що очікують на суд, ізольовано від засуджених, доцільність вилучення молоді зі сфери дії традиційної системи кримінального права, включаючи юрисдикцію судів у справах неповнолітніх або дітей, тощо). Проте, і досі, на думку I.C. Чалого, як чоловіки, так і жінки, стикаються 3 перешкодами для успішної реабілітації і соціальної реінтеграції. Деякі з цих бар'єрів $\epsilon$ інституційними, а інші стосуються індивідуальних обставин. Часто бракує політичної волі та бюджету на реабілітаційні програми, в'язниці іноді погано обладнані і не вистачає людських та фінансових ресурсів для забезпечення стабільної реалізації проектів. [36, с. 27-28; 45; 46, c. 83-84]. 
Важливо, також врахувати європейські міжнародні стандарти. Основними нормативно-правовими актами, що були ратифіковані Україною та стосуються питань виправлення і ресоціалізації засуджених $є$ Європейська Конвенція про захист прав людини та основоположних свобод (ETS 5), Рекомендація R (92) 16 Комітету міністрів державам-членам про Європейські правила щодо загальних санкцій та заходів, Рекомендація R (99) 22 щодо переповнення в'язниць і скорочення кількості ув'язнених, Рекомендація CM/Rec (2010) 1 про правила Ради Європи з питань пробації, Рекомендація № $\mathrm{R}$ (2006)2 Європейські пенітенціарні (в'язничні) правила та ін $[47 ; 48 ; 49 ; 50 ; 51]$.

Європейська конвенція про захист прав людини і основоположних свобод грунтується на положеннях Загальної декларації прав людини. Стаття 3 Конвенції визначає, що нікого не може бути піддано катуванню або нелюдському чи такому, що принижує гідність, поводженню або покаранню. Згідно ст. 5 нікого не може бути позбавлено свободи, крім таких випадків і відповідно до процедури, встановленої законом [11, с. 642; 47].

Європейські правила щодо загальних санкцій та заходів, затверджені рекомендацією R (92) 16 Комітету міністрів державам-членам, було прийнято 19 жовтня 1992 року. У правилах зазначається, що їх застосування повинно спонукати на підтримання рівноваги між необхідністю захисту суспільства з одного боку, і соціальної адаптації правопорушників з іншого [47; 52, с. 89].

Важливим також $є$ розширення інституту медіації у кримінальних справах в межах законодавства України. Так, відповідно до положень Рекомендації № R (99) 19 Комітету міністрів Ради Європи державамчленам Ради, які зацікавлені в організації медіації у кримінальних справах, така процедура розвиває почуття відповідальності у злочинця, чим надає змогу для виправлення та призводить до реінтеграції та реабілітації засудженого. Наразі українське законодавство має ряд положень, що сприяють медіації у кримінальних справах, але досі немає чіткої регламентації вказаного процесу. 3 метою запровадити ефективну реалізацію медіації в України, було подано до Верховної Ради України проект закону України "Про медіацію”, проте він досі не був затверджений та не набрав законної сили $[53 ; 54]$.

Інші важливі аспекти ресоціалізації засуджених передбачені в положеннях Рекомендації № (99) 22 Комітету міністрів державамчленам стосовно переповненості в'язниць і зростання кількості ув'язнених. Так, за п. 1. Рекомендації (99) 22 позбавлення волі слід розглядати як крайню міру або захід покарання, а відповідно до п.3 прокурорів та суддів необхідно заохочувати до використання покарань альтернативних тюремному ув'язненню, п. 22 вказує, що ефективність санкцій має бути забезпечена розробкою та використанням надійних методик прогнозування та оцінки ризиків, а також стратегії нагляду 3 метою виявлення ризику схильності правопорушника до рецидиву і забезпечення громадського захисту i безпеки. Також, у положеннях рекомендації вказується, що умовнодострокове звільнення $€$ одним 3 
найбільш ефективних заходів, що робить істотний внесок у планове повернення правопорушника у суспільство. 3 цього приводу Рада Європи прийняла окрему рекомендацію під номером Rec (2003) 22 Комітету міністрів державам-членам про умовно-дострокове звільнення (далі - Рекомендація (2003) 22). Відповідно до ії положень, п.4.а, 3 метою зменшення шкідливого впливу позбавлення волі, закон повинен зробити умовно-дострокове звільнення доступним для всіх засуджених, у тому числі тих, які відбувають довічне ув'язнення. Також, за п.8 для скорочення ризику рецидиву серед в'язнів, звільнених умовно, можно застосовувати програми лікування від наркотичної залежності або зловживання алкоголем, залучення до професійної діяльності, отримання освіти, чи професійного навчання на рівні із забороною проживання або відвідування місць, що створюють ризики повторного вчинення злочину. Проте, неодноразово зверталась увага України на переповненість установ виконання покарань, неналежні для засуджених кількість та якість продуктів харчування, медичну допомогу, умови перевезення, брак денного світла та свіжого повітря, невиправдані режимні обмеження тощо [49; 55; 56, с. 14$]$.

Рекомендація № $\mathrm{R}$ (2006)2 “ $\Theta_{\mathrm{B}}$ ропейські пенітенціарні (в'язничні) правила" у п. 5 та 7 проголошує, що життя в місцях позбавлення волі повинно бути, наскільки це можливо, наближене до позитивних аспектів життя у суспільстві і необхідно заохочувати співробітництво із зовнішніми соціальними службами та, наскільки можливо, залучати громадянське суспільство до участі у питаннях в'язничного життя. Відповідно до п. 17.1 ув'язнені повинні направлятися для відбуття покарання в пенітенціарні установи, розташовані поблизу від міста проживання або місць соціальної реабілітації (social rehabilitation). Положення п. 26.7 вказують, що організація та методи роботи $\mathrm{y}$ виправних установах повинні максимально відповідати організації та методам аналогічної роботи у суспільстві для того, щоб підготувати ув'язнених до умов нормального професійного життя. 3 огляду на різноманітність юридичних, соціальних, економічних i географічних умов зрозуміло, що не всі правила можна застосовувати повсюди й водночас. $\mathrm{V}$ Рекомендації $\mathrm{R}$ (2006)2 теж вказується, що Комітет Міністрів лише рекомендує урядам держав-учасниць керуватися в законодавстві, політиці та практиці вказаними правилами [51; 56, с. 48-49; 57; 58, с. 144].

Серед іншого, Україною було ратифіковано Рекомендацію CM/Rec (2010) 1 про правила Ради Європи 3 питань пробації від 20 січня 2010 року. I хоча сам акт не має обов'язкового характеру, проте містить у собі досвід держав-членів Ради Європи 3 найбільш розвинутими пенітенціарними системами. Важливою відмінністю європейських стандартів пробації від українських $\epsilon$ активне залучення засуджених до обрання шляхів і методів власного виправлення. Так, відповідно до п. 46 Рекомендації (2010) 1 засудженому має бути надана можливість брати участь в підготовці доповіді-рекомендації щодо можливості звільнення та застосування заходів виховної дії, i, по можливості, його думка має бути в 
нім відбита, він і (або) його законні представники мають бути ознайомлені зі змістом доповіді. Відповідно до п.52 Рекомендації (2010) 1, при призначенні громадських робіт у якості покарання, із засудженим необхідно обговорювати який вид робіт вони можуть виконувати. Положення п. 62 вказують, що функція допомоги у соціальній адаптації полягає у наданні допомоги засудженим вести законослухняний спосіб життя за їх згодою після виконання постпенітенціарних обов'язків Згідно до п. 66-68 Рекомендації (2010) 1 засуджений повинен, за можливості, брати активну участь у оцінці можливості скоєння нового злочину, обрання необхідних методів впливу, висловлювати власні думки і бажання, проявляти відповідальність за свої дії. Також засуджений зобов'язаний володіти інформацією щодо проведення пенітенціарної оцінки можливих ризиків та ії результатів. Дана практика дозволяє розвинути у засудженого такі позитивні риси, як відповідальність, ініціативність, самокритичність та вимогливість до себе та своїх результатів. Особиста зацікавленість та бажання засудженого $є$ необхідним елементом його ефективного виправлення та якнайшвидшої адаптації у суспільстві. Міжнародні стандарти й принципи поводження 3 ув'язненими наголошують на тому, що необхідно створювати умови, які дають в'язням можливість займатися корисною оплачуваною працею, що полегшить їх реінтеграцію на ринку робочої сили власних країн i зобов'яже їх надавати фінансову допомогу своїм сім'ям і родичам. Не менш актуальним залишається і питання запровадження електронного моніторингу засудженого, що передбаче- но п. $57 \quad 3 \quad$ метою виправлення (rehabilitation) і зниження рівня контролю [50; 59, с. $114 ; 60$, с. $169 ; 61$; 62].

Висновки. Міжнародні нормативно-правові акти містять положення, що стосуються виправлення та ресоціалізації засуджених, проте вони не систематизовані і зустрічаються у різних за юридичною силою та часом прийняття документах. Для їх виокремленого дослідження вказані стандарти, мають бути належним чином окреслені та структуровані. Найбільш вдалою класифікацією щодо положень, які регулюють виправлення та ресоціалізацію засуджених $є$ оновлена модель розподілу за двома основними критеріями: загальні (спільні для всіх норми й правила) та спеціальні (норми й правила, що стосуються окремих категорій засуджених).

Так, до загальних належать: заборона застосування тортур або інших жорстоких, нелюдських, таких, що принижують гідність, видів поводження i покарання; заборона примусової чи обов'язкової праці; гуманне поводження i повага до гідності; депеналізація та декриміналізація покарань, зменшення кількості осіб, які потрапляють у місця позбавлення волі шляхом пріоритетного застосування заходів пробації; розробка індивідуальних комплексних програм з виправлення та ресоціалізації засуджених, що передбачають освітню та професійну підготовку, роботу або будь-яку іншу допомогу, необхідну для успішної реінтеграції.

Міжнародні стандарти, що належать до категорії спеціальних доцільно розділити на 4 основні групи: 
1) щодо неповнолітніх необхідно застосовувати заходи, альтернативні позбавленню волі, заохочувати встановлення вільних контактів 3 жителями місцевої громади; проводити співбесіди з метою підготовки психологічного і соціального звіту, раннє умовне звільнення з виправної установи.

2) щодо жінок необхідно застосовувати заходи захисту їх прав, особливо вагітних жінок чи матерівгодувальниць; приділяти підвищену увагу здоров'ю; розробляти та впроваджувати методи класифікації 3 урахуванням особливих потреб і обставин жінок-ув'язнених, обумовлених гендерними факторами.

3) щодо працівників установ виконання покарань необхідно забезпечити захист засуджених від зловживання під час застосування заходів наведення порядку в пенітенціарних установах; повну охорону здоров'я та можливість надання медичної допомоги у разі потреби; сприяти реабілітаційному середовищу у виправних закладах, розвитку міжвідомчої координації.

4) щодо осіб, засуджених до альтернативних ув'язненню видів покарання необхідним $\epsilon$ їх активне залучення до обрання шляхів і методів власного виправлення; обговорення виду робіт, який вони можуть виконувати; активна участь в оцінці можливості скоєння нового злочину; запровадження електронного моніторингу; створення умов, які дають можливість займатися корисною оплачуваною працею.

Імплементація до національного законодавства та успішна реалізація вищевказаних положень має стати пріоритетним напрямом реформування пенітенціарної системи України з метою підвищення ефективності виправлення та ресоціалізації засуджених.

\section{Список використаних джерел}

1. Кримінально-виконавче право України: підручник / за заг. наук. ред. Є. Ю. Бараша. Київ: НАВС, 2018. Т1. 364 с.

2. Колб О. Г., Кухта М. Про зміст поняття “міжнародні стандарти поводження із засудженими". Електронний науковий архів Науково-технічної бібліотеки Національного університету "Львівська політехніка". 2020. Львів. С. 161-162.

3. Титушкина Е. Ю. Международно-правовые стандарты в сфере предупреждения преступлений и их реализация в законодательстве России. Академическая мысль. 2020. № 3(12). С. 133-136.

4. Слінько Т. М. Міжнародно-правові стандарти в галузі прав людини та їх відображення в Конституції України. 2018. С. 30-34.

5. Степанюк А. Х., Яковець I. С. Втілення міжнародних стандартів у практику діяльності кримінально-виконавчої системи України: монографія. Харків: Кросроуд, 2007. 184 c.

6. Рабінович П. М. Міжнародні стандарти прав людини: властивості, загальне поняття, класифікація. Вісник Національної академії правових наук України. 2016. № 1(84). С. 19-29.

7. Іваньков О. І. Міжнародно-правові стандарти у сфері забезпечення захисту прав засуджених до позбавлення волі: автореф. дис. ... канд. юрид. наук: 12.00.08. Харків, 2016. 19 с. 
8. Загальна декларація прав людини: декларація, міжнародний документ від 10.12.1948. URL: https://zakon.rada.gov.ua/laws/show/995_015 (дата звернення: 09.04.2021).

9. Міжнародний пакт про громадянські і політичні права ООН: пакт, міжнародний документ від 16.12.1966. URL: https://zakon.rada.gov.ua/laws/ show/995_043 (дата звернення: 09.04.2021).

10. International Covenant on Civil and Political Rights: pact, international document from 16.12.1966. pp. 171-346 URL: https://treaties.un.org/doc/ publication/unts/volume\%20999/volume-999-i-14668-english.pdf (дата звернення: 09.04.2021).

11. Уголовно-исполнительное право России: теория, законодательство, международные стандарты, отечественная практика конца XIX - начала XXI века: учебник / под общ. ред. А. И. Зубкова. Москва: Норма, 2006. 720 с.

12. Орлов В. Н. Применение и отбывание уголовного наказания: дис. ... д-ра юрид. наук: 12.00 .08 / Московский государственный юридический университет имени О.Е. Кутафина (МГЮА). Москва, 2015. 605 с.

13. Мінімальні стандартні правила поводження з в'язнями ООН: правила, міжнародний документ від 30.08.1955. URL: https://zakon.rada.gov.ua/ laws/show/995_212 (дата звернення: 10.04.2021).

14. Декларація про захист усіх осіб від катувань та інших жорстоких, нелюдських або таких, що принижують гідність, видів поводження і покарання ООН: резолюція, декларація, міжнародний документ від 09.12.1975. URL: https://zakon.rada.gov.ua/laws/show/995_084 (дата звернення: 20.03.2021).

15. Конвенція проти катувань та інших жорстоких, нелюдських або таких, що принижують гідність, видів поводження і покарання ООН: конвенція, міжнародний документ від 10.12.1984. URL: https://zakon.rada.gov.ua/laws/show/995_085 (дата звернення: 10.04.2021).

16. Резолюція 34/169 Генеральної Асамблеї ООН "Кодекс поведінки посадових осіб з підтримання правопорядку" ООН: резолюція, міжнародний документ, кодекс від 17.12.1979. URL: https://zakon.rada.gov.ua/laws/show/995_282 (дата звернення: 20.03.2021).

17. Мінімальні стандартні правила Організації Об'єднаних Націй, що стосуються відправлення правосуддя щодо неповнолітніх ("Пекінські правила") ООН: правила, міжнародний документ від 29.11.1985. URL: https://zakon.rada.gov.ua/laws/show/995_211 (дата звернення: 20.03.2021).

18. Резолюція 43/173 Генеральної Асамблеї ООН від 9 грудня 1988 року "Звід принципів захисту всіх осіб, які піддаються затриманню чи ув'язненню будь-яким чином ООН: Резолюція, Міжнародний документ від 09.12.1988. URL: https://zakon.rada.gov.ua/laws/show/995_206 (дата звернення: 10.04.2021).

19. Правила Організації Об'єднаних Націй щодо захисту неповнолітніх, позбавлених волі ОOH: правила, міжнародний документ від 14.12.1990. URL: https://zakon.rada.gov.ua/laws/show/995_205 (дата звернення:10.04.2021).

20. Керівні принципи запобігання злочинності серед неповнолітніх організації Об'єднаних Націй (Ер-Ріядські керівні принципи) ООН: принципи, міжнародний документ від 14.12.1990. URL: https://zakon.rada.gov.ua/laws/show/995_861 (дата звернення: 10.04.2021).

21. Standard Minimum Rules for the Treatment of Prisoners: rules, international document from 30.08.1955. URL: https://www.unodc.org/pdf/criminal_justice/UN_Standard_Minimum_Rules_for_the_Treatment_of_Prisoners.pdf (дата звернення: 10.04.2021).

22. Минимальные стандартные правила Организации Объединенных Наций в отношении обращения с заключенными (Правила Нельсона Манделы). UNODC Управление Организации Объединенных Наций по наркотикам и преступности, с. 38. 
URL: $\quad$ https://www.unodc.org/documents/justice-and-prison-reform/SMRbrochures/ UN_Standard_Minimum_Rules_for_the_Treatment_of_Prisoners_the_Nelson_Mandela_RulesR.pdf (дата звернення: 11.04.2021).

23. Перрон Ю. В. Новеллы Минимальных стандартных правил Организации Объединенных Наций в отношении обращения с заключенными (правила Нельсона Манделы). Пенитенциарная наука. 2017. №. 1(37). С. 62-66.

24. Адоевская О. А. Конвенционные нормы о ресоциализации осужденных. Юридический вестник Самарского университета. 2019. № 5(1). С. 52-58.

25. Мигаль Р. В. Катування: кримінологічний аспект: дис. ... канд. юрид. наук: 12.00.08 / Львівський університет бізнесу та права. Львів, 2020. 229 с.

26. Гальцова О. В., Степанюк А. Х. Принцип поваги до прав і свобод людини у кримінально-виконавчому законодавстві, виконанні і відбуванні покарань: монографія. Харків: Право, 2020. 224 с.

27. United Nations Standard Minimum Rules for the Administration of Juvenile Justice (the Beijing Rules). Compendium of United Nations standards and norms in crime prevention and criminal justice. pp 51-116.

28. Широкова-Мурараш О. Г. Вдосконалення системи відправлення правосуддя по відношенню до неповнолітніх за мінімальними стандартними правилами ООН (Пекінські правила). Міжнародні відносини: теоретико-практичні аспекти. 2020. № 5. C. 117-131.

29. United Nations Rules for the Protection of Juveniles Deprived of their Liberty: resolution 45/113 of 14 December 1990 pp 1-10.

30. Музика В. В. Міжнародно-правова основа виконання покарання у виді позбавлення волі стосовно неповнолітніх. Юридичний бюлетень. 2020. Вип. 15. С. 122129.

31. Мінімальні стандартні правила Організації Об'єднаних Націй у відношенні заходів, не пов'язаних з тюремним ув'язненням (Токійські правила): резолюція, міжнародний документ від 14.12.1990. URL: https://zakon.rada.gov.ua/laws/show/995_907 (дата звернення: 22.03.2021).

32. United Nations Standard Minimum Rules for Non-custodial Measures (the Tokyo Rules). Compendium of United Nations standards and norms in crime prevention and criminal justice. pp 117-136. URL: https://www.unodc.org/pdf/criminal_justice/ UN_Standard_Minimum_Rules_for_Non-custodial_Measures_Tokyo_Rules.pdf (дата звернення: 22.03.2021).

33. Сборник стандартов и норм Организации Объединенных Наций в области предупреждения преступности и уголовного правосудия. ООН. 2016. Нью Йорк. с. 536. URL: https://www.unodc.org/documents / justice-and-prison-reform/R_ebook.pdf (дата звернення: 24.04.2021).

34. United Nations Rules for the Treatment of Women Prisoners and Non-custodial Measures for Women Offenders with their Commentary. United Nations Office of Drugs and Crime. 2011. p. 50 URL: https://www.unodc.org/ documents/justice-and-prisonreform/Bangkok_Rules_ENG_22032015.pdf (дата звернення: 14.04.2021).

35. Про Національну стратегію у сфері прав людини: указ Президента України № 119/2021 від 24.03.2021. URL: https://www.president.gov.ua/ documents/119202137537 (дата звернення: 14.04.2021).

36. Батиргареєва В. С. Питання боротьби з рецидивною злочинністю у матеріалах конгресів ООН щодо запобігання злочинності та поводження з правопорушниками. Питання боротьби зі злочинністю. 2020. Вип. 39. С. 23-31.

37. Иващук В. К. К вопросу об истории формирования международных стандартов борьбы с преступностью. Труды Академии управления МВД России. 2018. № 3(47). C. 13-18.

62 । С торінка 
38. Конгрессы Организации Объединенных Наций по предупреждению преступности и уголовному правосудию 1955-2020 годы Достижения за 65 лет. UNODC. Киото. 2020. с. $17 . \quad$ URL: https://www.unodc.org/documents/congress// About/information/65-years-brochure_ru.pdf (дата звернення: 14.04.2021).

39. Одиннадцатый Конгресс Организации Объединенных Наций по предупреждению преступности и уголовному правосудию. A/CONF.203/15. Бангкок. 2005. c. 21.

40. Двенадцатый Конгресс Организации Объединенных Наций по предупреждению преступности и уголовному правосудию. A/CONF.213/L.2. Сальвадор. 2010. c. 9.

41. Четырнадцатый Конгресс Организации Объединенных Наций по предупреждению преступности и уголовному правосудию. A/CONF.234/4. Кіото. 2020. с. 21.

42. Кримінально-виконавче право. Словник-довідник / автори-упорядники: С. Ф. Денисов, Т. А. Денисова, М. В. Пузиревський. Чернігів : Десна Поліграф, 2020. 712 с.

43. Fourteenth United Nations Congress on Crime Prevention and Criminal Justice. A/CONF.234/L.6. Kyoto 2021, c. 13.

44. Денисова Т. А. Покарання у системі протидії злочинності. Вісник Асоціації кримінального права України. 2013. № 1(1). С. 409-423.

45. Роль, функции, периодичность и продолжительность конгрессов Организации Объединенных Наций по предупреждению преступности и обращению с правонарушителями: принята на 56-й сессии резолюцией Генеральной Ассамблеи ООН от 23 января 2002 г. No 56/119. A/RES/56/119. URL: https://undocs.org/ru/A/RES/56/119 (дата звернення: 15.04.2021).

46. Чалий I. С. Соціальна реабілітація засуджених: дис. ... канд. юрид. наук : 12.00.08 / Класичний приватний університет. Запоріжжя, 2021. 218 с.

47. Рекомендація N R (92) 16 Комітету міністрів державам-членам про Європейські правила щодо загальних санкцій та заходів Рада Європи: рекомендації, міжнародний документ від 19.10.1992 № R(92)16. URL: https://zakon.rada.gov.ua/laws/show/995_907 (дата звернення: 15.03.2021).

48. Конвенція про захист прав людини і основоположних свобод: конвенція, міжнародний документ від 04.11.1950. URL: https://zakon.rada.gov.ua/ laws/show/995_004 (дата звернення: 25.03.2021).

49. Комітет міністрів державам-членам стосовно переповненості в'язниць і зростання кількості ув'язнених: Рекомендація від 30.09.1999 р. № (99) 22. URL: https://rm.coe.int/16806f407b (дата звернення: 14.04.2021).

50. Про правила Ради Європи з питань пробації: Рекомендація від 20.01.2010 р. № CM/Rec (2010) 1. URL: https://rm.coe.int/16806f4097 (дата звернення: 14.04.2020).

51. Європейські пенітенціарні (в'язничні) правила: рекомендації, міжнародний документ від 12.02.1987. Дата оновлення: 11.01.2006. URL: https://zakon.rada.gov.ua/laws/show/994_032 (дата звернення: 25.03.2021).

52. Уткин В. А. Международные стандарты уголовно-исполнительной деятельности и стереотипы их восприятия. Уголовная юстищия. 2016. № 2(8). С. 89-96.

53. Комітет міністрів Ради Європи державам-членам Ради, які зацікавлені в організації медіації у кримінальних справах: Рекомендація від 15.09.1999 р. № N R (99) 19. URL: https://zakon.rada.gov.ua/laws/show/994_828 (дата звернення: 24.03.2021).

54. Про медіацію: проект Закону України від 19.05.2020 р. № 3504. URL: http://w1.c1.rada.gov.ua/pls/zweb2/webproc4_1?pf3511=68877 (дата звернення: 25.03.2021). 
55. Комітет міністрів державам-членам про умовно-дострокове звільнення: Рекомендація від 24.09.2003 p. № $\operatorname{Rec}(2003)$ 22. URL: https://zakon.rada.gov.ua/laws/show/994_665 (дата звернення: 14.04.2021).

56. Краснокутський 0. В. Міжнародно-правові механізми забезпечення прав засуджених до позбавлення волі: дис. ... канд. юрид. наук : 12.00 .08 / Науководослідний інститут вивчення проблем злочинності імені академіка В. В. Сташиса Національної академії правових наук України. Харків, 2019. с. 201.

57. Recommendation $\operatorname{Rec}(2006) 2-\mathrm{rev}$ of the Committee of Ministers to member States on the European Prison Rules from 12.02.1987. Revised on 01.07.2020. URL: https://search.coe.int/cm/Pages/result_details.aspx?ObjectId=09000016809ee581 (дата звернення: 25.03.2021).

58. Лисодєд О. В. Загальна декларація прав людини і міжнародні стандарти поводження із засудженими. Проблеми законності. 2008. № 99. С. 141-146.

59. Засоби виправлення і ресоціалізації засуджених до позбавлення волі: монографія /за заг. ред. А. Х. Степанюка. Харків. 2011. 323 с.

60. Іваньков О. І., Бондар I. В. Окремі питання реформування служби пробації в Україні. Юридичний науковий електронний журнал. 2018. № 5. С. 167-170.

61. Про пробацію: Закон України від 05.02.2015 р. № 160-VIII. Дата оновлення: 01.01.2021. URL: https://zakon.rada.gov.ua/laws/show/160-19 (дата звернення: 14.04.2021).

62. Recommendation $\mathrm{CM} / \operatorname{Rec}(2010) 1$ of the Committee of Ministers to member states on the Council of Europe Probation Rules from 20.01.2010. URL: https://www.pmscr.cz/download/mezdoken_European_Probation_Rules.pdf (дата звернення: 15.04.2021).

\section{References}

Barash, Ye. Yu. (red.). (2018). Kriminalno-vikonavche pravo Ukrayini. Kiyiv: NAVS.

Kolb, O. G., Kuhta, M. (2020). Pro zmist ponyattya "mizhnarodni standarti povodzhennya iz zasudzhenimi". Elektronnij naukovij arhiv Naukovo-tehnichnoyi biblioteki Nacionalnogo universitetu "Lvivska politehnika". Lviv, 161-162.

Titushkina, E. Yu. (2020). Mezhdunarodno-pravovye standarty v sfere preduprezhdeniya prestuplenij i ih realizaciya v zakonodatelstve Rossii. Akademicheskaya mysl, 3(12), 133-136.

Slinko, T. M. (2018). Mizhnarodno-pravovi standarti v galuzi prav lyudini ta yih vidobrazhennya $v$ Konstituciyi Ukrayini.

Stepanyuk, A. H., Yakovec, I. S. (2007). Vtilennya mizhnarodnih standartiv u praktiku diyalnosti kriminalno-vikonavchoyi sistemi Ukrayini. Harkiv: Krosroud.

Rabinovich, P. M. (2016). Mizhnarodni standarti prav lyudini: vlastivosti, zagalne ponyattya, klasifikaciya. Visnik Nacionalnoyi akademiyi pravovih nauk Ukrayini, 1(84), 19-29.

Ivankov, O. I. (2016). Mizhnarodno-pravovi standarti u sferi zabezpechennya zahistu prav zasudzhenih do pozbavlennya voli: avtoref. dis. ... kand. yurid. nauk. Harkiv.

Orlov, V. N. (2015). Primenenie i otbyvanie ugolovnogo nakazaniya: dis. ... d-ra yurid. nauk. Moskovskij gosudarstvennyj yuridicheskij universitet imeni O.E. Kutafina (MGYuA). Moskva.

Perron, Yu. V. (2017). Novelly Minimalnyh standartnyh pravil Organizacii Obedinennyh Nacij v otnoshenii obrasheniya s zaklyuchennymi (pravila Nelsona Mandely). Penitenciarnaya nauka, 1(37), 62-66.

Adoevskaya, O. A. (2019). Konvencionnye normy o resocializacii osuzhdennyh. Yuridicheskij vestnik Samarskogo universiteta, 5(1), 52-58.

Migal, R. V. (2020). Katuvannya: kriminologichnij aspekt: dis. ... kand. yurid. nauk. Lvivskij universitet biznesu ta prava. Lviv. 
Galcova, O. V., Stepanyuk, A. H. (2020). Princip povagi do prav i svobod lyudini u kriminalno-vikonavchomu zakonodavstvi, vikonanni i vidbuvanni pokaran. Harkiv: Pravo.

Batirgareyeva, V.S. (2020). Pitannya borotbi z recidivnoyu zlochinnistyu u materialah kongresiv OON shodo zapobigannya zlochinnosti ta povodzhennya z pravoporushnikami. Pitannya borotbi zi zlochinnistyu, 39, 23-31.

Ivashuk, V. K. (2018). K voprosu ob istorii formirovaniya mezhdunarodnyh standartov borby s prestupnostyu. Trudy Akademii upravleniya MVD Rossii, 3(47), 13-18.

Denisova, T. A. (2013). Pokarannya u sistemi protidiyi zlochinnosti. Visnik Asociaciyi kriminalnogo prava Ukrayini, 1(1), 409-423.

Chalij, I. S. (2021). Socialna reabilitaciya zasudzhenih: dis. ... kand. yurid. nauk. Klasichnij privatnij universitet. Zaporizhzhya.

Utkin, V. A. (2016). Mezhdunarodnye standarty ugolovno-ispolnitelnoj deyatelnosti i stereotipy ih vospriyatiya. Ugolovnaya yusticiya, 2(8), 89-96.

Krasnokutskij, O. V. (2019). Mizhnarodno-pravovi mehanizmi zabezpechennya prav zasudzhenih do pozbavlennya voli: dis. ... kand. yurid. nauk. Naukovo-doslidnij institut vivchennya problem zlochinnosti imeni akademika V. V. Stashisa Nacionalnoyi akademiyi pravovih nauk Ukrayini. Harkiv.

Lisodyed, O. V. 2008 Zagalna deklaraciya prav lyudini i mizhnarodni standarti povodzhennya iz zasudzhenimi. Problemi zakonnosti, 99, 141-146.

Stepanyuk, A. H. (red.). (2011). Zasobi vipravlennya i resocializaciyi zasudzhenih do pozbavlennya voli. Harkiv.

Ivankov, O. I., Bondar, I. V. (2018). Okremi pitannya reformuvannya sluzhbi probaciyi v Ukrayini. Yuridichnij naukovij elektronnij zhurnal, 5, 167-170.

S. Denysov, Doctor of Law, Professor, Professor of the Department of Criminal Law and Criminology, faculty №6, Kharkiv National University of Internal Affairs e-mail:dsf7002@gmail.com;ORCID: 0000-0002-1218-0016

D. Zaika, Postgraduate student of the Department of Criminal Law and Criminology, faculty №6, Kharkiv National University of Internal Affairs

e-mail: zaika.workspace@gmail.com

\section{International legal standards on correction and resocialization of convicted persons}

Correction and resocialization of convicted persons is the leading task of the penitentiary systems of most countries. One of the components of its effective implementation is compliance with international standards. However, today there is no single legal act aimed at resolving the problematic issues of correction and resocialization of convicts, so there is a need for their separation and further elaboration. The article examines international legal acts adopted by the United Nations and the Council of Europe on general human rights or special provisions governing the treatment of convicts. To implement the tasks, the current international regulations and materials of existing research were analyzed; identified among them provisions relating to the correction and re-socialization of convicts; united them on common grounds and formulated their own conclusions. According to the results, it was determined that international standards contain a number of important provisions that require more detailed analysis. The authors outlined the main requirements of the international community for the effective functioning of the peniten-

(C) Денисов С. Ф., Заїка Д. Є., 2021

65 | Сторінка 
tiary system as a whole and the direct correction and re-socialization of convicts. All requirements were analyzed and grouped according to updated modern model of classification of international legal standards of the UN and the Council of Europe in the field of protection of the rights of prisoners to imprisonment according to two main criteria: general, which include general norms and rules relating to human rights and special, which determine the norms and rules concerning certain categories of persons sentenced to imprisonment, in particular: women; minors; staff of penitentiary institutions, etc.

In conclusion, the authors point out that the implementation of national legislation and the successful implementation of the above provisions should become a priority in reforming the penitentiary system of Ukraine in order to increase the effectiveness of correction and re-socialization of convicts.

Keywords: correction and resocialization; international aspect; rules; declaration; UN General Assembly; UN conventions; resolutions; international standards of treatment of convicts. 